Piotr Chybalski

\title{
Dopuszczalność udziału posła, w ramach interwencji poselskiej, w kontroli prowadzonej przez powiatowy inspektorat nadzoru budowlanego ${ }^{1}$
}

Admissibility of Deputy's participation, within the frame of a Deputy's intervention, in the control carried out by the County's Inspectorate of Construction Supervision: The institution of intervention was constructed in the Act on the Exercise of the Exercise of a Mandate of a Deputy or Senator in a relatively inaccurate way. The author of the opinion states that in the analyzed situation a Deputy is not entitled to participate in the inspection carried out by the County's Inspectorate of Construction Supervision. The only legal requirements concerning the intervention concern informing the Deputy about the state of consideration the case, being the subject of the intervention, and defining the date of "the final consideration of the case".

Keywords: intervention, mandate, construction supervision, Deputy

Słowa kluczowe: interwencja, mandat, nadzór budowlany, poseł

\section{Przedmiot opinii}

Przedmiotem opinii jest analiza dopuszczalności udziału posła - $\mathrm{w}$ ramach tzw. interwencji poselskiej, o której mowa w art. 20 ustawy z 9 maja 1996 r. o wykonywaniu mandatu posła i senatora (t.j. Dz.U. 2018, poz. 1799; dalej: u.w.m.p.s.) w kontroli prowadzonej przez powiatowy inspektorat nadzoru budowlanego. U źródeł realizowanego zlecenia leży pismo Powiatowego Inspektora Nadzoru Budowlanego w W. z 20 września 2018 r., w którym czytamy m.in., że: ustawa

Opinia prawna w sprawie dopuszczalności udziału posła, $w$ ramach interwencji poselskiej, w kontroli prowadzonej przez powiatowy inspektorat nadzoru budowlanego sporządzona 23 października 2018 r. na zlecenie Klubu Poselskiego Kukiz’15; BAS-WAKiU 2259/18. 
o wykonywaniu mandatu posła i senatora, ustawa Prawo budowlane oraz ustawa Kodeks postępowania administracyjnego, nie daje [posłowi - przyp. P.Ch.] uprawnień do udziału w czynnościach prowadzonych przez organ nadzoru budowlanego $w$ terenie.

\section{Interwencja poselska jako jedno $z$ uprawnień parlamentarzysty}

Uregulowana w art. 20 u.w.m.p.s. tzw. interwencja poselska (senatorska) należy do tych uprawnień przysługujących parlamentarzystom, które wywołują szczególnie liczne kontrowersje zarówno wśród korzystających zeń posłów i senatorów, jak i w doktrynie prawa. Instytucja interwencji została skonstruowana bowiem w sposób stosunkowo nieostry. Prima facie może ona mylnie jawić się jako daleko idące (w zasadzie „władcze”) uprawnienie wiążące się z mandatem parlamentarnym. Ponadto została ona wprowadzona w stanie prawnym obowiązującym przed wejściem w życie Konstytucji RP z 1997 r., co może rodzić wątpliwości w kontekście jej dostosowania do obowiązujących rozwiązań ustrojowych, w szczególności zakresu tzw. funkcji kontrolnej wykonywanej w świetle ustawy zasadniczej przez Sejm.

Zgodnie $\mathrm{z}$ art. 20 ust. 1 u.w.m.p.s. poseł lub senator ma prawo podjąć - w wykonywaniu swoich obowiązków poselskich lub senatorskich - interwencję w organie administracji rządowej i samorządu terytorialnego, zakładzie lub przedsiębiorstwie państwowym oraz organizacji społecznej, a także w jednostkach gospodarki niepaństwowej dla załatwienia sprawy, którą wnosi we własnym imieniu albo w imieniu wyborcy lub wyborców, jak również zaznajamiać się $\mathrm{z}$ tokiem jej rozpatrywania. Obowiązki adresata interwencji określone zostały w art. 20 ust. 2 i 3 u.w.m.p.s., obejmując: a) powiadomienie posła lub senatora, najpóźniej w ciągu czternastu dni od podjęcia interwencji, o stanie rozpatrywania sprawy (ust. 2); b) „ostateczne załatwienie” sprawy w terminie uzgodnionym z posłem lub senatorem, a także c) niezwłoczne przyjęcie przez kierowników organów i jednostek, o których mowa w przywołanym wyżej art. 20 ust. 1, posła lub senatora, który przybył w związku ze sprawą wynikającą z wykonywania jego mandatu, oraz udzielenie informacji i wyjaśnień dotyczących sprawy. Z kolei w ramach prowadzonej interwencji posłowi (senatorowi) przysługuje, na podstawie legitymacji poselskiej (senatorskiej), prawo wstępu na teren jednostek, o których mowa w art. 20 ust. 1 u.w.m.p.s.

W piśmiennictwie konstytucyjnym interwencja poselska (senatorska) jest opisywana jako uprawnienie mające dwa - realizowane łącznie bądź alternatywnie - cele, tj. umożliwienie parlamentarzyście uzyskanie informacji o przebiegu sprawy rozpatrywanej przez dany podmiot bądź też doprowadzenie do jej osta- 
tecznego rozstrzygnięcia ${ }^{2}$. Drugi ze wskazanych celów wskazuje, że interwencja umożliwia posłowi (senatorowi) wywarcie wpływu na organ rozpatrujący sprawę, w związku z którą realizowana jest interwencja. Nie oznacza to jednak, że parlamentarzysta może, podejmując interwencję, nałożyć na ów organ obowiązek załatwienia sprawy w pożądany przez parlamentarzystę sposób. Jak bowiem wynika z przywołanych wyżej przepisów, obowiązki adresata interwencji wyrażają się, co do zasady, w zagwarantowaniu parlamentarzyście wstępu na teren jednostki, w której prowadzona jest interwencja, osobistym przyjęciu posła (senatora) przez kierownika jednostki, a także poinformowaniu interweniującego o stanie rozpatrzenia sprawy oraz ustaleniu terminu (nie zaś sposobu) jej „ostatecznego załatwienia”. Warto dodać, że w zakresie nieuregulowanym w art. 20 u.w.m.p.s. stosuje się wszystkie przepisy odnoszące się do danej sprawy stanowiącej przedmiot interwencji. Brak jest podstaw prawnych, aby, stosując szeroką (de facto rozszerzającą) wykładnię art. 20, „przełamywać” za pomocą tego przepisu inne obowiązujące rozwiązania prawne, a więc „odnajdywać” w interwencji poselskiej (senatorskiej) nieprzewidziane expressis verbis w ustawie szczegółowe uprawnienia parlamentarzysty, które mogłyby być wykonywane w ramach podjętej interwencji. Jedynie w odniesieniu do kwestii wprost uregulowanych w art. 20 (choćby w obszarze „prawa wstępu” z ust. 4) można stwierdzić, że przepisy tego artykułu mogą $\mathrm{w}$ kolizji z innymi regulacjami potencjalnie przeważać jako tzw. lex specialis. Wspomniana nieostrość art. 20 u.w.m.p.s. sprawia jednak, że każdą sytuację występującą w praktyce należy analizować osobno, na zasadzie a casu ad casum.

\section{Udział posła w kontroli prowadzonej przez Powiatowego Inspektora Nadzoru Budowlanego}

Dotychczasowe ustalenia wskazują, że wspomniane wyżej stanowisko zawarte w piśmie Powiatowego Inspektora Nadzoru Budowlanego w W. jest trafne. Zakładając, że w analizowanym przypadku adresatem interwencji poselskiej był właśnie ten organ, nie ulega wątpliwości, że wykonującemu interwencję posłowi nie przysługiwało uprawnienie w zakresie udziału w czynnościach urzędowych podejmowanych przez powiatowego inspektora nadzoru budowlanego. Prawnie wymagane było jedynie przyjęcie posła, poinformowanie o stanie rozpatrzenia sprawy, z którą związana była interwencja, a także określenie terminu „ostatecznego rozpatrzenia sprawy".

W uzupełnieniu należy odnotować, że udział posła w kontroli Powiatowego Inspektora Nadzoru Budowlanego nie byłby wymagany na podstawie przepisów

P. Uziębło, Uwagi do art. 20 [w:] K. Grajewski, J. Stelina, P. Uziębło, Komentarz do ustawy o wykonywaniu mandatu posła i senatora, Warszawa 2014, s. 281. 
określających tryb przeprowadzania tego typu kontroli, gdyż przepisy te nie wymieniają parlamentarzystów wśród osób, w obecności których przeprowadza się kontrole. Zgodnie z art. 81a ust. 2 ustawy z 7 lipca 1994 r. - Prawo budowlane (t.j. Dz.U. 2018, poz. 1202, ze zm.) czynności kontrolne, związane z wykonywaniem uprawnień organów nadzoru budowlanego, przeprowadza się w obecności inwestora, kierownika budowy lub robót, kierownika zakładu pracy lub wyznaczonego pracownika bądź osób przez nich upoważnionych albo w obecności właściciela lub zarządcy obiektu, a w lokalu mieszkalnym - w obecności pełnoletniego domownika i przedstawiciela administracji lub zarządcy budynku. Z kolei (ust. 3) $\mathrm{w}$ przypadku kontroli podmiotu niebędącego przedsiębiorcą, $\mathrm{w}$ razie nieobecności osób, o których mowa w ust. 2, w uzasadnionych przypadkach czynności kontrolne mogą być dokonywane w obecności przywołanego pełnoletniego świadka, a (ust. 4) czynności kontrolne dotyczące obiektów budowlanych, które są w zarządzie państw obcych albo są użytkowane przez przedstawicieli dyplomatycznych i konsularnych tych państw lub przez inne osoby zrównane z nimi na podstawie ustaw, umów lub powszechnie ustalonych zwyczajów międzynarodowych, mogą być wykonywane za zgodą tych przedstawicieli lub osób.

\section{Podsumowanie}

Posłowi nie przysługuje, $\mathrm{w}$ ramach prowadzonej interwencji poselskiej, prawo uczestnictwa w kontroli prowadzonej przez powiatowy inspektorat nadzoru budowlanego.

\section{Bibliografia}

Grajewski K., Stelina J., Uziębło P., Komentarz do ustawy o wykonywaniu mandatu posła i senatora, Warszawa 2014. 